\title{
Comparative Study between Augmentation Skin Mastopexy versus Augmentation Glandular mastopexy after Massive Weight Loss Moustafa H. ELHelw ${ }^{1,}$ Ahmed M. ELMofty ${ }^{2}$, Magdy A. Abd Al Moktader ${ }^{2}$, Tarek M. ELBanoby ${ }^{2}$, Amir A. Saedy ${ }^{1}$,Ahmed A. ELDanaf ${ }^{1}$ \\ (1): Plastic \& Reconstructive Surgery Department, Mataria Teaching Hospital \\ (2): Plastic \& Reconstructive Surgery Department, AL Azhar University \\ *Corresponding author: Moustafa H. ELHelw, E-Mail: drmust.hassan@ gemail.com, Mobile: 01122276012
}

\begin{abstract}
Background: an increase in the number of massive weight loss patients resulted in increase of body contouring surgery including breast reshaping.

Aim of the study: it was to compare two procedures of augmentation skin mastopexy augmentation skin glandular mastopexy with analysis and evaluation of the final aesthetic results.

Patients and Methods: forty female patients after massive weight loss patients were included in this study, divided in to two groups. 20 patients underwent augmentation skin mastopexy (A) and the other 20 patients underwent augmentation skin-glandular mastopexy (B). Augmentation was done through implant. Breast measurements and aesthetic outcome were assessed.

Results: both groups showed well improvement in breast shape, volume, and projection with no significant difference regards patient satisfaction and expectations and measurements.

Conclusion: augmentation mastopexy as a combined procedure is a good solution for breast ptosis after massive weight loss. Skin glandular mastopexy is the same as skin mastopexy but it showed fewer complications, no revision, and more satisfaction than skin mastopexy.
\end{abstract}

Keywords: augmentation mastopexy, massive weight loss, breast.

\section{Introduction}

The mammary gland forms one of the most attractive areas of the female anatomy. As a beautiful, harmonious gland is essential for sensuality a lot of surgical procedures for improving its look were introduced ${ }^{(\mathbf{1}, 2)}$. More complex and challenging manipulations are needed in massive weight loss (MWL) patients. The surgeon should understand each deformity clearly to get an aesthetically pleasing result ${ }^{(3)}$.

Changes of the upper body after massive weight loss (MWL) include breast flaccidity and ptosis, loss projection, flattening, inframammary fold (IMF) and nipple descent, back rolls, and arms changes ${ }^{(4)}$. The most important thing to obtain good and log-term results with minimal complication rate is the selection of the surgical technique of augmentation mastopexy $y^{(5)}$.

The safety of single-stage augmentation-mastopexy is still controversial. There are concerns about the technically challenging nature of the procedure, expansion of breast volume and reduction of the skin envelope $^{(\mathbf{6})}$.

In this study we aim to clarify which is better of the two procedures, augmentation skin mastopexy and augmentation glandular mastopexy in massive weight loss patients, regarding safety, complications, and aesthetic outcome.

\section{Patients and Methods}

This is a prospective study included 40 female patients presented with breast ptosis and atrophy after massive weight loss. We started surgery when patient weight is fixed for at least 6 months. The included criteria were age : 20-60 years, BMI: 20-30, healthy patients, no breast tumors, and no previous breast surgery. The cases were divided randomly into two groups, 20 patients, skin mastopexy group $\mathrm{A}$, the other 20 patients, skin-glandular mastopexy group B. The study was done at Al-Azhar University Hospitals and Mataria Teaching Hospital from February 2016 till September 2018. Local examination to breast and axillae, degree of ptosis, and chest circumference were assessed.

Marking was done while the patients standing. While the patient in a supine position, here arms were abducted 70-90 degree, and under G.A surgery was started. Creation of the subglandular pocket and insertion of the implant after proper haemostasis was done. Excess skin was tightened in a vertical fashion while the patient in near semisetting position. 
Deepethelialization of the skin within the marking was done keeping the areola within $4.2 \mathrm{~cm}$. In group A: releasing of skin was done till proper closure and NAC reaching its new position with no tension. In group B: creation of superior pedicle and excising small triangular tissue inferior to the pedicle to create medial and lateral pillars were done. Closure was done in two layers; third layer of closure (pillars) was added in group B.

Ethical and approval considerations were taken from Faculty of Medicine, AlAzhar University Ethical Comity.

Data Management and Analysis:

The collected data was revised, coded, tabulated and introduced to a PC using Statistical package for Social Science (SPSS 15.0 for windows; SPSS Inc, Chicago, IL, 2001). Data was presented and suitable analysis was done according to the type of data obtained for each parameter.

\section{i. Descriptive statistics:}

- Frequency and percentage of non-numerical data.

- Mean.

○ Standard deviation $( \pm \mathrm{SD})$.

$\circ \quad$ Minimum and maximum values (range) for numerical data.

\section{ii. $\quad$ Analytical statistics:}

1. The Independent-Samples $\mathbf{T}$ Test was used to assess the statistical significance of the difference between two study group means. \{N.B: Independent-Sample $\mathrm{T}$ Test cannot be produced and $\mathrm{t}$ cannot be computed because the mean and standard deviations of both groups are 0$\}$.

2. Chi-Square test was used to examine the relationship between two qualitative variables.

3. Fisher's exact Chi-Square test is computed when a table that does not result from missing rows or columns in a larger table has a cell with an expected frequency of less than 5 .

- P-value: level of significance $-\mathrm{P}>0.05$ : Not significant (NS). $-\mathrm{P} \leq 0.05$ : Significant (S). $-\mathrm{P} \leq 0.01$ : Highly significant (HS).

\section{Results}

There was no statistically significant difference, between the two studied groups regards age, BMI, ptosis, way of weight loss, amount of weight loss, marital status, lactation, habits, chronic diseases, the implant size, and breast size and volume (Fig. 1-3)(Tab 1-3).

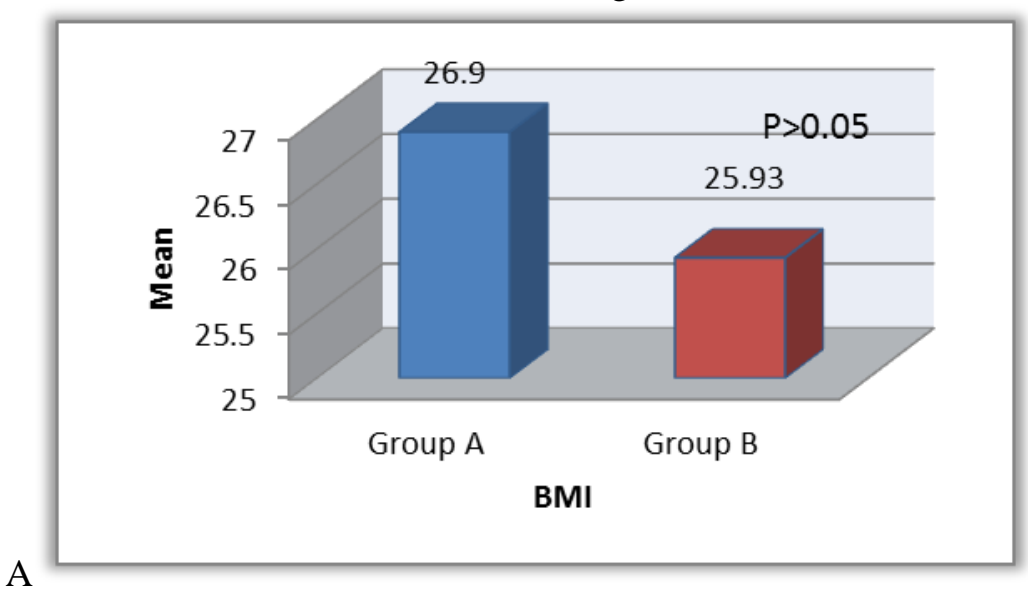


Comparative Study between Augmentation Skin Mastopexy versus Augmentation Glandular...

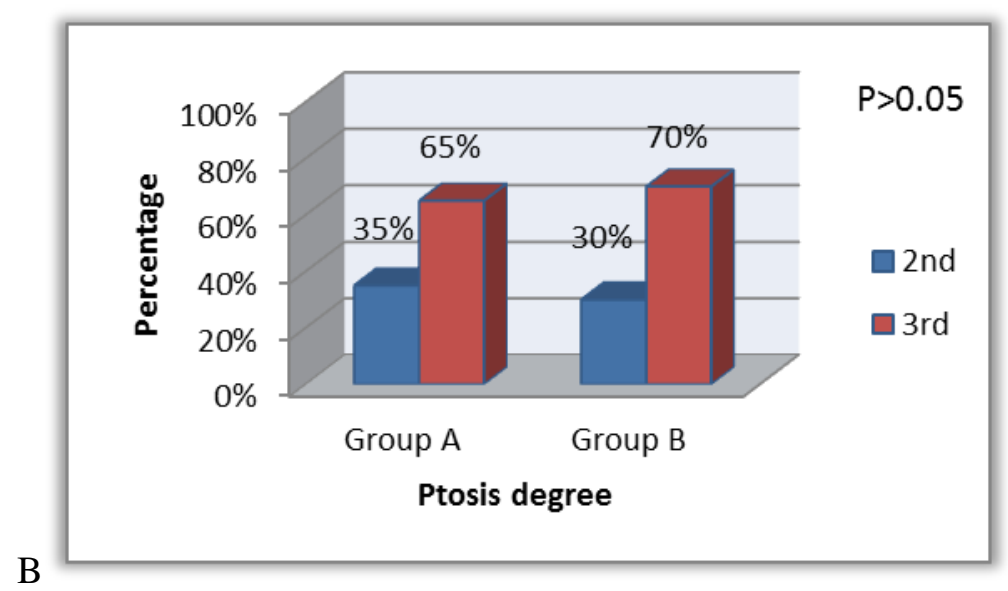

Fig.1: Bar charts representing comparison between the two groups regards A:Ptosis degree, B: BMI Tab. 1: Comparison between the two groups regards BMI

$\begin{array}{llllll}\text { BMI N } & \text { Mean } & \text { SD } & \text { t } & \text { P Value }\end{array}$

\begin{tabular}{ccccccc}
\hline \hline Group $\boldsymbol{A}$ & 20 & 26.90 & 1.41 & \multirow{2}{*}{1.73} & 0.093 & NS \\
Group $\boldsymbol{B}$ & 20 & 25.93 & 2.08 & & \\
\hline \hline
\end{tabular}

The Independent-Samples $T$ Test

Tab. 2: Comparison between the two groups regards Ptosis degree

\begin{tabular}{|c|c|c|c|c|c|c|}
\hline Ptosis degree & $\begin{array}{c}\text { Group A } \\
(\mathbf{n}=\mathbf{2 0})\end{array}$ & $\begin{array}{c}\text { Group B } \\
(n=20)\end{array}$ & $\begin{array}{c}\text { Total } \\
(n=40)\end{array}$ & $\mathrm{X} 2$ & P Value & Sig. \\
\hline 2nd & $7(35.0 \%)$ & $6(30.0 \%)$ & $13(32.5 \%)$ & \multirow{2}{*}{0.739} & \multirow{2}{*}{0.11} & \multirow{2}{*}{ NS } \\
\hline $3 r d$ & $13(65.0 \%)$ & $14(70.0 \%)$ & $27(67.5 \%)$ & & & \\
\hline
\end{tabular}

\section{Chi-Square test}
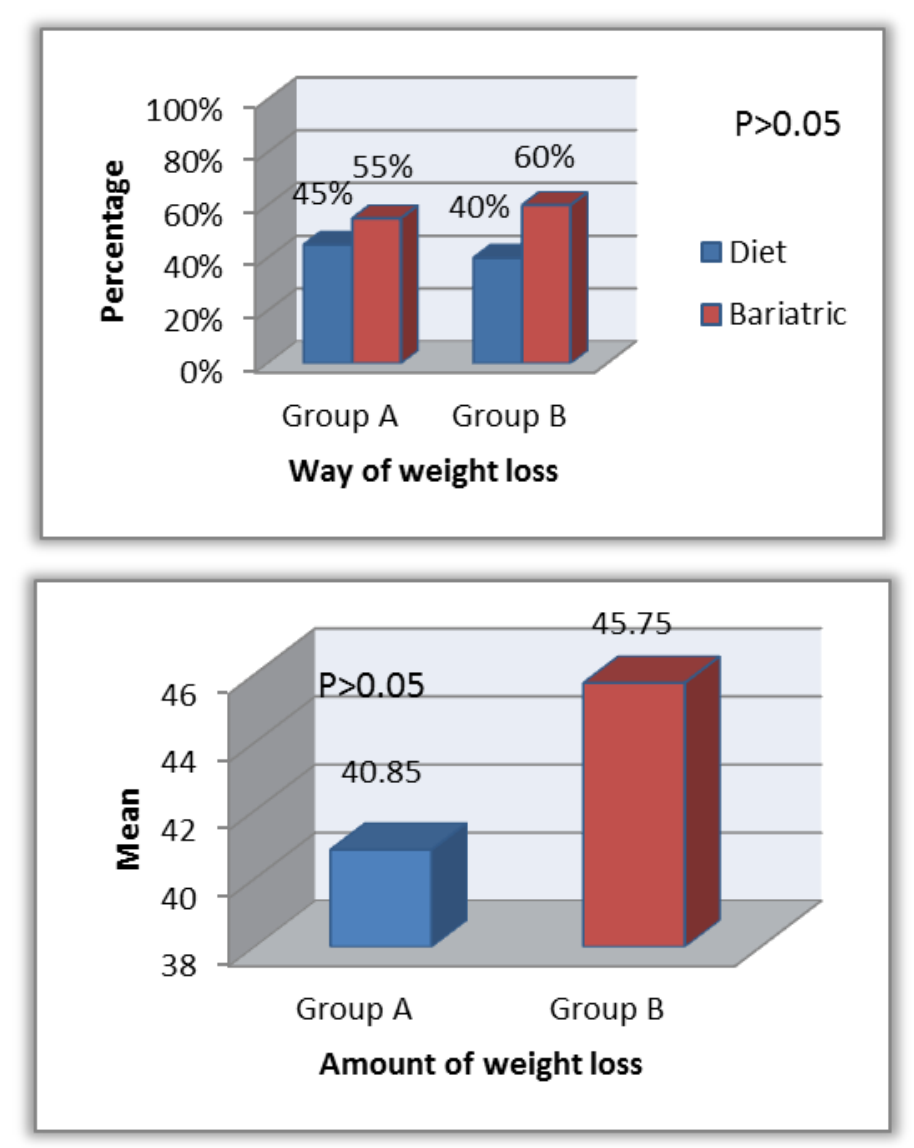
Fig. 2: Bar charts representing comparison between the two groups regards above: way of weight loss, below: amount of weight loss

Table 3: Comparison between the two groups regards amount of weight loss

\begin{tabular}{ccccccc}
\hline Amount of weight loss & N & Mean & SD & $\mathbf{t}$ & P Value & Sig. \\
\hline \hline Group $A$ & 20 & 40.85 & 12.11 & -1.33 & 0.191 & NS \\
\hline Group $\boldsymbol{B}$ & 20 & 45.75 & 11.15 & \\
\hline \hline
\end{tabular}

The Independent-Samples T Test


Fig. 3: Bar charts representing comparison between the two groups regards above: implant size, below breast size/ volume

There was no statistically significant difference, between the two studied groups regards areola elevation, vertical scar measurements, and type of scar (Fig. 4) (Tab. 4-5).

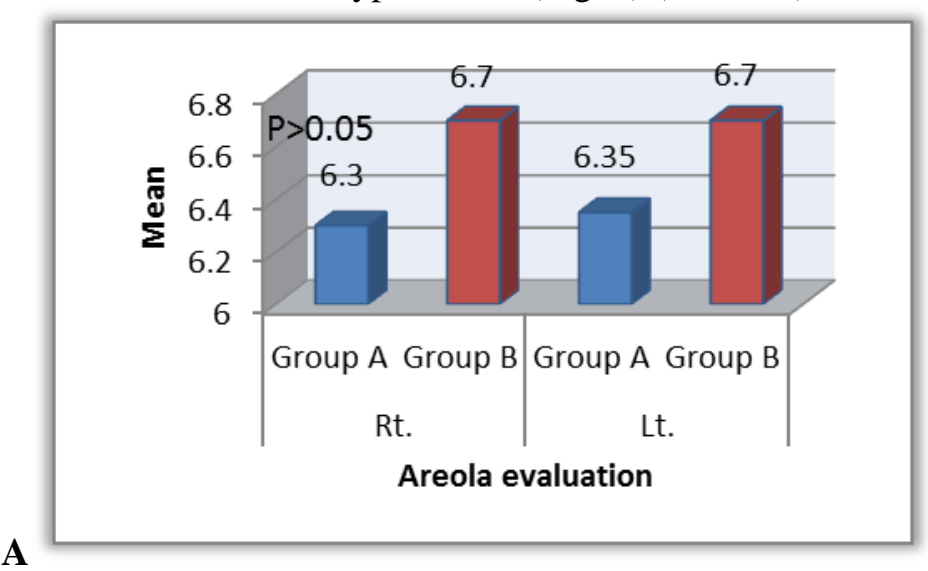


Comparative Study between Augmentation Skin Mastopexy versus Augmentation Glandular...



Fig. 4: Bar charts representing comparison between the two groups regards A: areola evaluation, B: vertical scar, C: scar type

Table 4: Comparison between the two groups regards areola evaluation

\begin{tabular}{|c|c|c|c|c|c|c|c|}
\hline \multicolumn{2}{|c|}{ Areola evaluation } & $\mathbf{N}$ & Mean & SD & $\mathbf{t}$ & $P$ Value & Sig. \\
\hline \multirow{2}{*}{ Rt. } & Group A & 20 & 6.30 & 2.13 & \multirow[t]{2}{*}{-0.61} & \multirow[t]{2}{*}{0.547} & \multirow[t]{2}{*}{ NS } \\
\hline & Group B & 20 & 6.70 & 2.03 & & & \\
\hline \multirow{2}{*}{ Lt. } & Group A & 20 & 6.35 & 2.37 & \multirow[t]{2}{*}{-0.54} & \multirow[t]{2}{*}{0.594} & \multirow[t]{2}{*}{ NS } \\
\hline & Group B & 20 & 6.70 & 1.69 & & & \\
\hline
\end{tabular}

\section{The Independent-Samples $T$ Test}

Tab. 5: Comparison between the two groups regards scar type

\begin{tabular}{ccccccc}
\hline Scar type & $\begin{array}{c}\text { Group A } \\
(\mathbf{n}=\mathbf{2 0})\end{array}$ & $\begin{array}{c}\text { Group B } \\
(\mathbf{n}=\mathbf{2 0})\end{array}$ & $\begin{array}{c}\text { Total } \\
(\mathbf{n}=\mathbf{4 0})\end{array}$ & $\mathbf{X 2}$ & P Value & Sig. \\
\hline \hline Inverted $T$ & $55.0 \%$ & $45.0 \%$ & $50.0 \%$ & & & \\
Periareoolar & $20.0 \%$ & $0 \%$ & $10.0 \%$ & 6.10 & 0.048 & NS \\
Vertical & $25.0 \%$ & $55.0 \%$ & $40.0 \%$ & & & \\
\hline
\end{tabular}

\section{Fisher's exact Chi-Square test}

Complications was happened in 9patients in group A and 6 patients in group B. Revision is done for one patient and scheduled for another patients, both in group A (Fig. 5-6) (Tab6). 




Fig. 5: Bar chart representing comparison between the two groups regards complications.

Tab. 6: Comparison between the two groups regards complication.

\begin{tabular}{|c|c|c|c|c|c|c|}
\hline Complication & $\begin{array}{c}\text { Group A } \\
(\mathrm{n}=\mathbf{2 0})\end{array}$ & $\begin{array}{l}\text { Group B } \\
(\mathrm{n}=20)\end{array}$ & $\begin{array}{c}\text { Total } \\
(\mathrm{n}=40)\end{array}$ & $\mathbf{X} 2$ & P Value & Sig. \\
\hline Asymmetry & $5.0 \%$ & $5.0 \%$ & $5.0 \%$ & \multirow{8}{*}{4.84} & \multirow{8}{*}{0.840} & \multirow{8}{*}{ NS } \\
\hline $\begin{array}{c}\text { Asymmetry \& implant } \\
\text { malposition }\end{array}$ & $5.0 \%$ & $5.0 \%$ & $5.0 \%$ & & & \\
\hline $\begin{array}{c}\text { Asymmetry \& Lt side implant } \\
\text { malposition }\end{array}$ & $5.0 \%$ & $5.0 \%$ & $5.0 \%$ & & & \\
\hline Capsular contracture & $5.0 \%$ & $\mathbf{0}$ & $2.5 \%$ & & & \\
\hline Implant malposition & $15.0 \%$ & $10.0 \%$ & $12.5 \%$ & & & \\
\hline$-v e$ & $55.0 \%$ & $70.0 \%$ & $62.5 \%$ & & & \\
\hline Wound dehiscence & $10.0 \%$ & $\mathbf{0}$ & $5.0 \%$ & & & \\
\hline $\begin{array}{l}\text { Wound dehiscence and } \\
\text { implant malpoosition }\end{array}$ & $\mathbf{0}$ & $5.0 \%$ & $2.5 \%$ & & & \\
\hline
\end{tabular}

\section{Fisher's exact Chi-Square test}
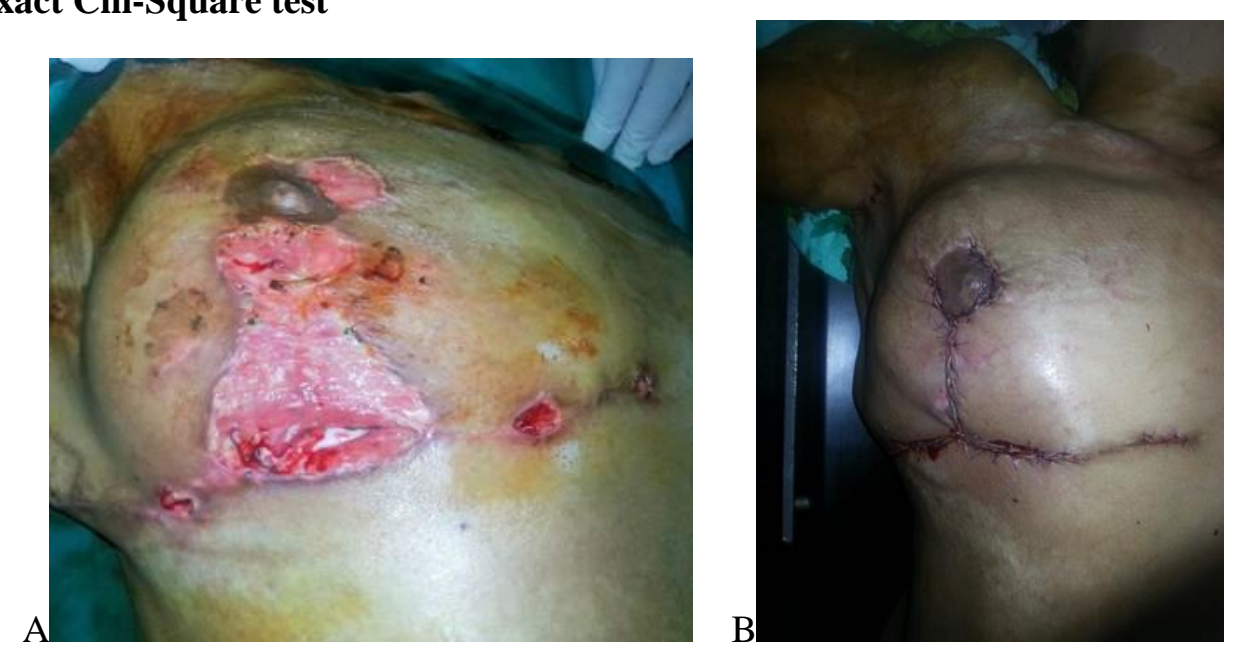
Comparative Study between Augmentation Skin Mastopexy versus Augmentation Glandular...

$\mathrm{C}$


Fig. 6: A: Wound dehiscence 12 days postoperative. B: 2ndry sutures immediate postoperative, C: implant malposition and capsular contracture: (Rt): three months post operative, (Lt): two weeks post revision mastopexy and implant changes.
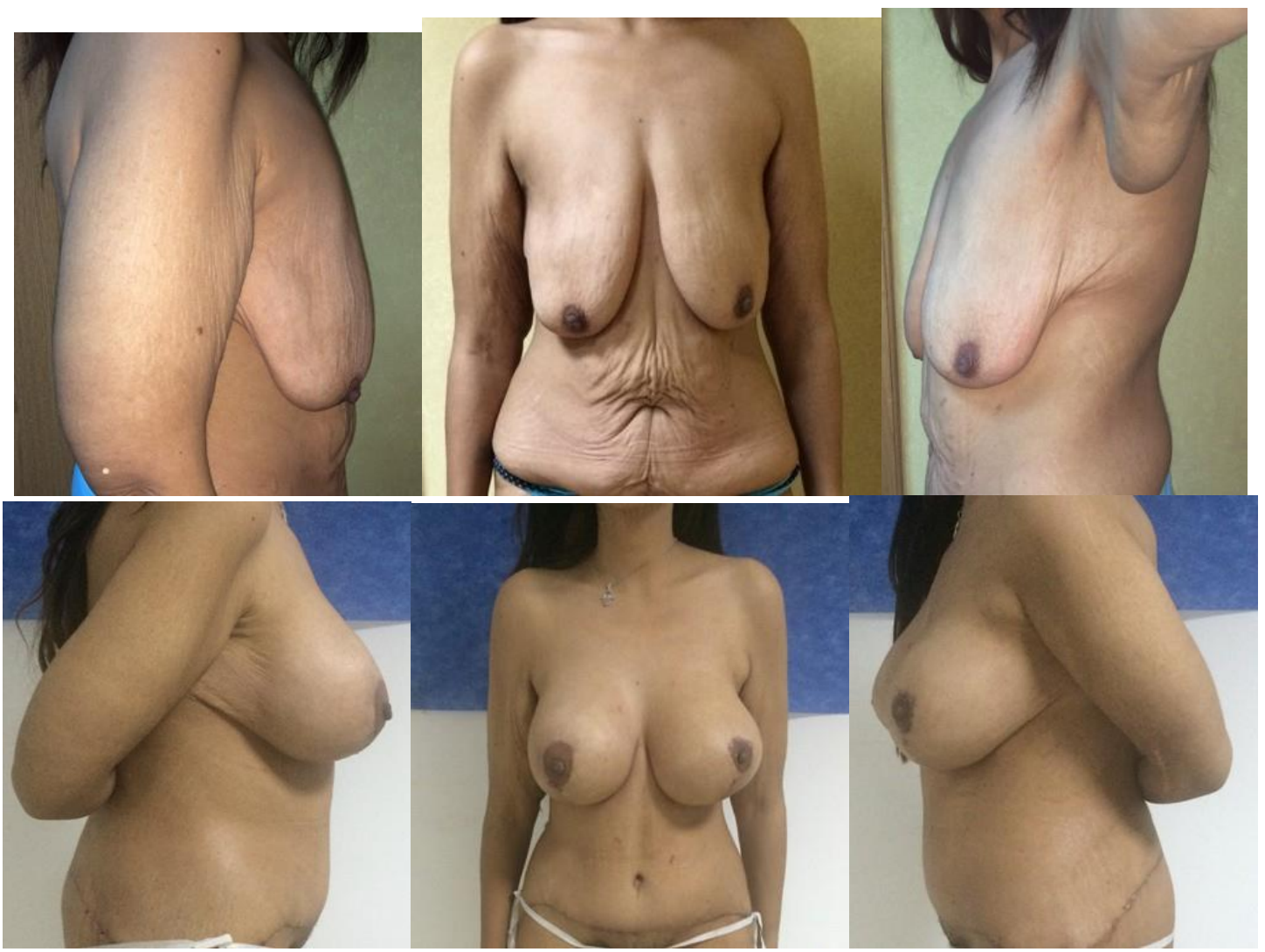

Fig.7: Group A: above: preoperative pictures. Below: eight months postoperative augmentation skin mastopexy with implant $455 \mathrm{cc}$.

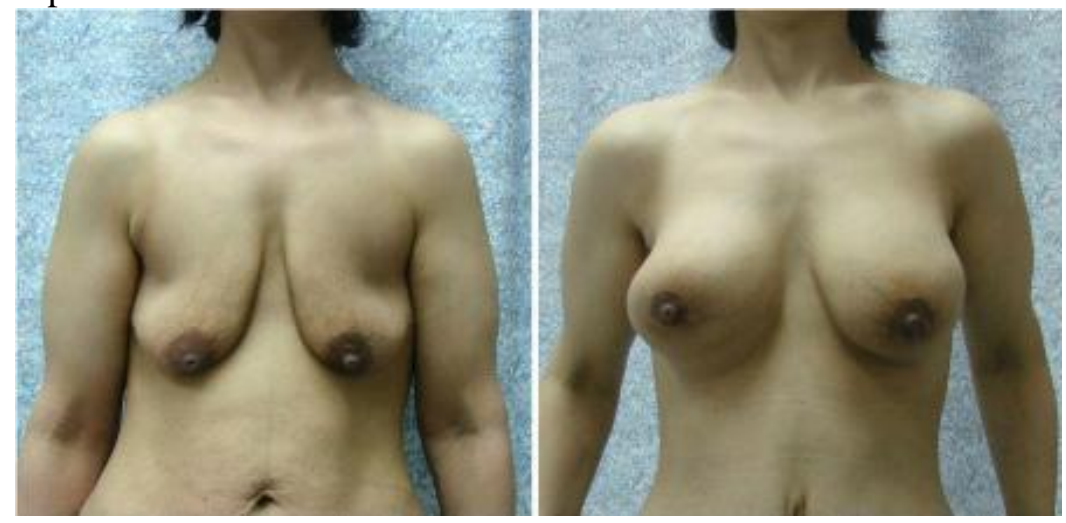



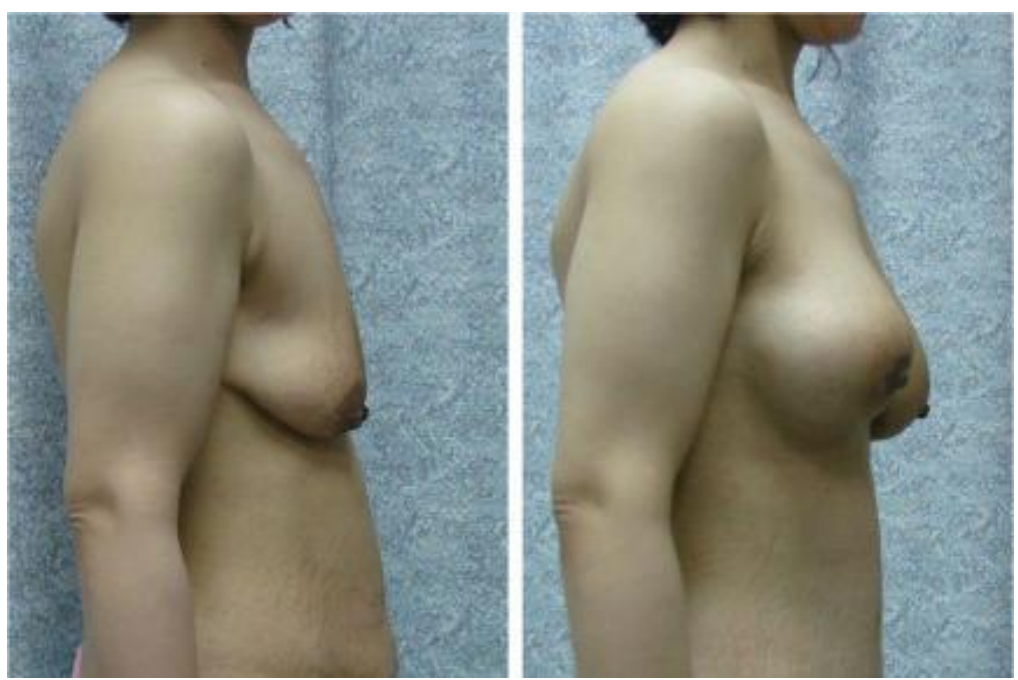

Fig. 8: Group A: Lt: preoperative pictures. Rt: six months postoperative augmentation skin mastopexy with implant 400cc.



Fig. 9:Lt: preoperative pictures. Rt: nine months postoperative augmentation skin glandular mastopexy with implant $375 \mathrm{cc}$. 

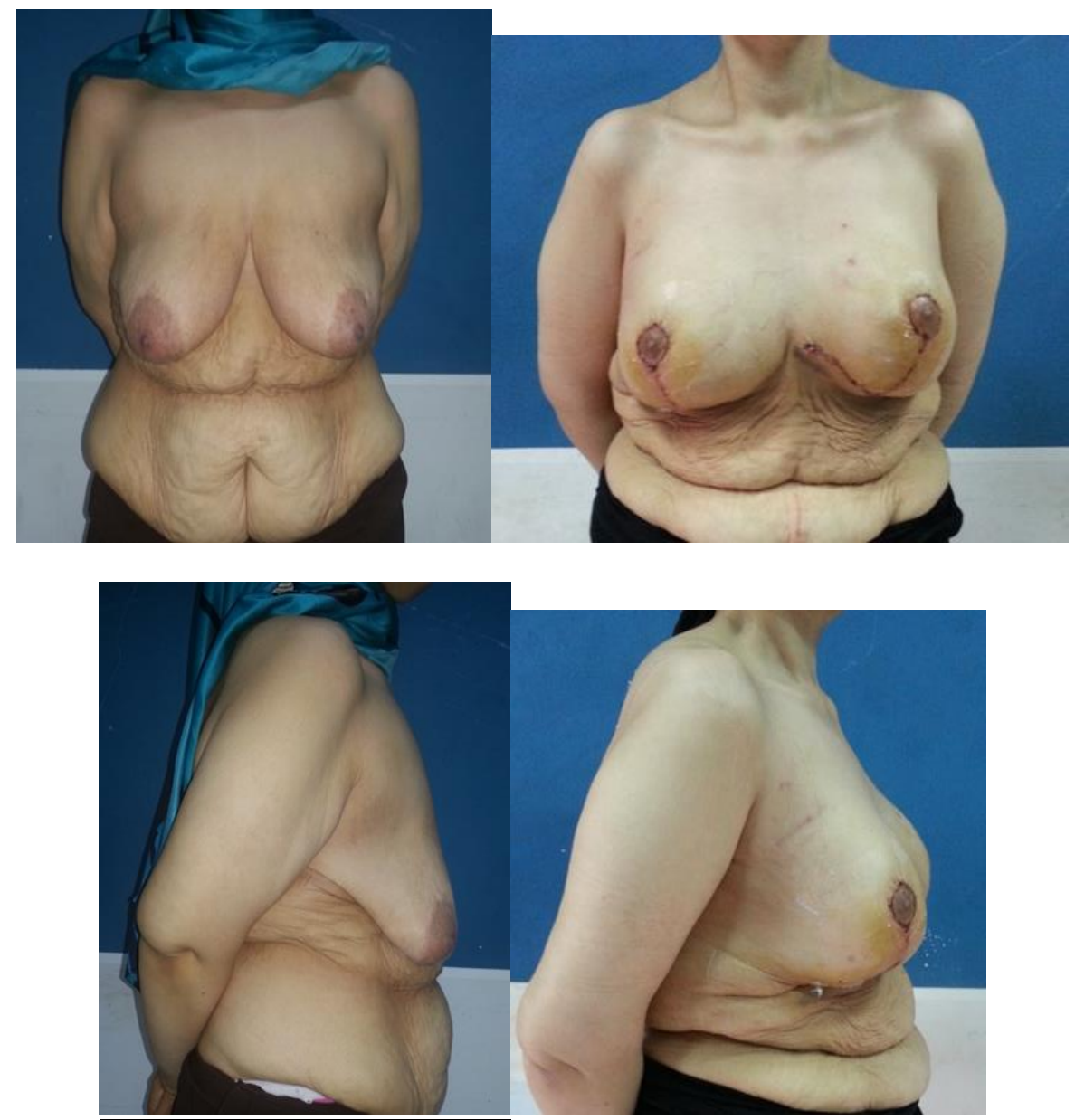

Fig. 10: preoperative pictures. Rt: six months postoperative augmentation skin glandular mastopexy with implant $315 \mathrm{cc}$.

\section{Discussion}

Body contouring after massive weight loss is an important plastic surgery procedure to improve a patient's quality of life ${ }^{(7)}$.

Good evaluation is an important to get low complication rate. Patient has to be involved in the decision and follow up, and any medical problem should be controlled before surgery.

Breast after massive weight loss shows severe ptosis, severe asymmetry, loss of upper pole volume, medial shift of the nippleareola complex, extension to a lateral chest roll, loss of lateral curvature of the breast, and a loose and lateral inframammary fold ${ }^{(8)}$.

Breast augmentation is indicated for inadequate breast volume which is due to hypoplasia or involutional changes. Involutional changes caused by postpartum breast, breastfeeding, hormonal changes and weight fluctuations. Its presented by decreased breast volume with excess of skin and subcutaneous tissue ${ }^{(9)}$.
In massive weight loss patient breast skin is not able to support an implant because of severe laxity. Also mastopexy alone will decrease breast volume and disrupt suspension structures of the breast. So augmentation with small to moderate sized implants with mastopexy should be preferred to increase volume and prevent recurrent ptosis ${ }^{(\mathbf{1 0})}$.

We agree that massive weight loss patient breast should be managed in both directions augmentation and mastopexy. But we halve to add that patients with good skin quality are better candidates for implant augmentation but for those with massive weight loss still dermal suspension techniques is needed.

Based on the clinical scenario, surgeon's experience and the patient's choice, The decision to stage or combine augmentation mastopexy is taken. This decision should not depend on a concern for increased risk to the patient and a review of the single-stage procedure. Revision rate and 
return to the operating room is $16.9 \%$ for combined single procedure compared with $100 \%$ of staged procedures requiring a second operation $^{(\mathbf{1 1})}$.

We are big fans for one stage procedure, augmentation mastopexy, especially for massive weight loss patients. Massive weight loss patients have to be informed that correction of their breast deformity is difficult, residual deformities or recurrent ptosis is common, some degree of asymmetry almost always occurs, and revision procedure may be required to reach an acceptable result.

Also we halve to inform patients about possibility of complications, what increases its rate, how could we lower it, and if happened how can we deal with it. Scar sites placements were also discussed with patients.

For increasing breast volume implants may be used to enhance shape and restore volume. Regardless of the technique, skin envelope reduction is a key component in shaping the female breast. Enhancing volume with implant is faster than autoaugmentation, more accurate, rapid learning curve, and accompanied with less complications with experienced hand. We used textured silicone implant to enhance the volume and skin envelope reduction was used as skin reduction only in one group and skin glandular reduction in the other group.

Skin augmentation mastopexy is easier and faster rather than skin glandular mastopexy as there is no need for flap and pillars creation, just augmentation followed by skin tightening as we found. Also we found that complication rate is higher and patient satisfaction is lower in this group than that in group B. Also secondary procedure was done in 2 patients in group $\mathrm{A}$, one secondary suture for wound dehiscence and another for capsular contracture.

We agree about that creation of medial and lateral pillars, proper haemostasis and washing then fixing the pillars will give good projection and lower chance of early ptosis.

The most common complication of the implants is capsular contracture, excessive fibrous scar tissue formation around the implant leading to firmness, distortion of the implant and pain. Implant removal or revision of excessive scar tissue may be required in $15 \%-35 \%$ of cases $^{(\mathbf{1 2})}$. Implant malposition is another common complication in massive weight loss patients undergoing breast

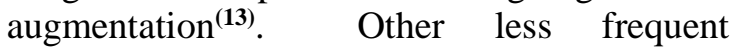
complications of breast implants are infection, malposition and rupture ${ }^{(\mathbf{1 2})}$. Common complications of breast lift with or without augmentation are hematoma, infection, Seroma and changes in NAC appearance and sensitivity ${ }^{(\mathbf{1 4})}$.

In our study $6(30 \%)$ patients had asymmetry, $3(15 \%)$ patients in each groups. Implant malposition was happened in $9(45 \%)$ patients, 5 patients in group A and 4 patients in group B. capsular contracture was happened in 1 patient (group A). wound dehiscence was found in 3 cases, 2 in group A and 1 in group B. revision was done for one patient (group A).

\section{Conclusion}

Augmentation mastopexy as a combined procedure is a good solution for breast ptosis after massive weight loss. Skin glandular mastopexy is the same as skin mastopexy plus lower pole glandular tissue resection with 2 pillars (medial \& lateral) creation. it shows less complications, no revision, and more satisfaction than skin mastopexy but for more accuracy it needs more studied, long duration follow up, more patients numbers, and multicentre ones.

\section{References}

1- Rohrich RJ, Gosman AA, Brown SA, Reisch J (2006): Mastopexy preferences: A survey of boardcertified plastic surgeons. Plast Reconstr Surg.,118:1631-1638.

2- - Rohrich RJ, Gosman AA, Brown SA et al. (2002): Current preferences for breast reduction techniques: A survey of board-certified plastic surgeons. Plast Reconstr Surg.,114:1724-1733.

3- Kwei S, Borud L and Lee B (2006): Mastopexy with autologus augmentation after massive weight loss: the intercostal perforator artery flap ICAP. Ann plast surg.,57(4): 361365.

4- Losken A (2010): Breast reshaping following massive weight loss: principles and techniques. Plast Reconstr Surg.,126:1075.

5- La' zaro $C$ and Roberto $R$ (2006): Augmentation/Mastopexy: How to Select and Perform the Proper 
Comparative Study between Augmentation Skin Mastopexy versus Augmentation Glandular...

Technique, Aesth. Plast. Surg.,30:2133.

6- Nima K, .Sumanas W, Aksharananda $\mathrm{R}$ et al. (2014): A Systematic Review of Single-Stage Augmentation-Mastopexy, Plast. Reconstr. Surg.,134: 922.

7- Kitzinger HB, Abayev S, Pittermann A et al. (2012): The prevalence of body contouring surgery after gastric bypass surgery. Obes Surg.,22:8-12.

8- Rubin JP, Gusenoff JA, and Coon D (2009): Dermal suspension and parenchymal reshaping mastopexy after massive weight loss: Statistical analysis with concomitant procedures from a prospective registry. Plast Reconstr Surg., 123:782-789.

9- Bradley C (2018): Breast augmentation, Plastic Surgery Book, $4^{\text {th }}$ edition, Peter C. Neligan.

10- Moustapha $H$ and Serhan $T$ (2012): Breast Surgery in Patients after Massive Weight Loss, Body Contouring Following Bariatric Surgery And Massive Weight Loss Book, Bishara S. Atiyeh and $\mathrm{M}$.
Costagliola, Bentham Science Publishers.

11- Emily C, Michelle A and Grant S (2018): One- and two-stage considerations for augmentation mastopexy, Plastic Surgery Book, $4^{\text {th }}$ edition, Peter C. Neligan.

12- Handel N, Cordray T, Gutierrez J, and Jensen JA (2006): A long-term study of outcomes, complications, and patient satisfaction with breast implants. Plast Reconstr Surg.,117: 757-767.

13- Demetrius M. Coombs, Udayan Srivastava, Dalit Amar et al. (2017): The Challenges of Augmentation Mastopexy in the Massive Weight Loss Patient: Technical Considerations, Plast. Reconstr. Surg., 139:1090.

14- Henriksen TF, Holmich LR, Friis $S$ et al. (2003): The Danish Registry for Plastic Surgery of the Breast: establishment of a nationwide registry for prospective follow-up, quality assessment, and investigation of breast surgery. Plast Reconstr Surg.,111: 2182-2189. 